\title{
LETTERS
}

J. Raptor Res. 48(3):292-294

(C) 2014 The Raptor Research Foundation, Inc.

\section{Cannibalism in Bonelli's Eagle (AQuila fasciata)}

KeY WORDS: Bonelli's Eagle; Aquila fasciata; Hieraaetus fasciatus; behavior; cannibalism; nesting.

Cannibalism, defined as the process of eating individuals of conspecifics at any stage of their life cycles (Polis 1981), is not rare in the animal kingdom (Fox 1975, Elgar and Crespi 1992, Ebensperger 1998). Among the different types of cannibalism, parental cannibalism involves the consumption of offspring by parents, a phenomenon that has been described for diverse animal species, including birds (Polis and Myers 1985, Kevles 1986, Mociño-Deloya et al. 2009).

In general, direct observations of bird cannibalism are fairly rare due to the relative scarcity of such events and the difficulty of continuous monitoring of large numbers of nests. Notwithstanding, cannibalism in wild populations has been recorded for diurnal raptors (Ingram 1959, Solaro and Sarasola 2012), owls (Ingram 1962) and colonial waterbirds (Stanback and Koenig 1992), and this behavior has also been observed in some species of the genus Aquila (Real 1991, García-Dios 2003, González et al. 2006, Korňan and Macek 2011). Here we report two cases of cannibalism for Bonelli's Eagle (Aquila fasciata) in the Iberian Peninsula.

The Bonelli's Eagle is rather large, long-lived, territorial, and monogamous species, with delayed maturity and low breeding rates (Cramp and Simmons 1980) that have markedly declined over recent decades, such that this species is classified as Endangered (IUCN category) in Europe (BirdLife International 2004). Nevertheless, this raptor has a positive conservation status in the southern Iberian Peninsula, where it nests primarily on cliffs within rugged landscapes (del Moral 2006, Hernández-Matías et al. 2013), and has reproductive rates of between 0.6 and 1.4 fledglings per occupying pair and year (del Moral 2006). Incubation and feeding young are done mainly by females (Arroyo et al. 1976).

For 20 yr (1994-2013), we have monitored a population of 22 territorial pairs on the southeastern Iberian Peninsula (Ontiveros 1999, Ontiveros et al. 2008). When possible, each territory was visited at least three times during breeding season, during incubation, close to hatching, and before fledging. Observations were conducted from prominent spots using $20-60 \times$ spotting scopes located approximately $200-800 \mathrm{~m}$ from the nest, a distance that did not disturb adult behavior.

On 8 May 2013, we observed an occupied Bonelli's Eagle nest in the Almijara Mountains (southern Granada province) starting at 12:00 $\mathrm{H}$; for at least $90 \mathrm{~min}$, both adults were on the nest. One adult, which we presumed was the male because of its smaller size, was tearing flesh and feeding on the carcass of the only nestling, which was approximately $35 \mathrm{~d}$ old judging by its size and feather development (Torres et al. 1981). We did not observe the female feeding on the nestling. Because we did not witness killing of the nestling, we could not determine whether the parent killed a live nestling or simply found it dead in the nest and opportunistically ate it. Clutch size was unknown because this was the first visit to this nest. However, 5 d later, on a second viewing of the nest from a closer location, we could see no remains from a second nestling in the nest.

In 2004, we also observed another incident of cannibalism by another pair in the same study population. On that occasion, we observed the female incubating two eggs on 8 March 2004. Two months later, on our second visit to check the status of the nest, we noted two young approximately $50 \mathrm{~d}$ old, one alive and the other dead and partially eaten. Again, it was not possible to determine whether the event was a consequence of opportunistic feeding on the carrion or from intentional killing of the offspring; on this occasion we could not discern whether the dead offspring was fed upon by the sibling or by the parents. On a subsequent visit, we observed the live young, approximately $65 \mathrm{~d}$ old, in the nest; Bonelli's Eagles are typically fledged at about 60 d old (Real and Mañosa 1997).

During the study period ( $20 \mathrm{yr}$ ) we monitored 389 nesting attempts, but these are the only two cases of cannibalism detected, and at least one of them clearly involved parental cannibalism. To our knowledge, there is only one published account of this behavior for Bonelli's Eagle (Real 1991), despite the fact that the species is well studied, particularly in the Iberian Peninsula (del Moral 2006).

In Bonelli's Eagles, nestlings frequently disappear from the nest for unknown reasons (Real 1987; J. Caro, D. Ontiveros, and J. Pleguezuelos unpubl. data). Larger raptors, such as the Golden Eagle (Aquila chrysaetos) and the Eurasian Eagle-Owl (Bubo bubo), may prey on incubating females and nestling Bonelli's Eagles (Real and Mañosa 1990). However, in the Bonelli's Eagle population from Catalonia, researchers documented some cases of brood reduction attributed to starvation, with subsequent plucking of nestlings, indicating possible cannibalism by adults or other nestlings (J. Real pers. comm.). Therefore, cannibalism may not be exceptional in this region. 
We propose two possible explanations for the feeding behavior observed. We believe that the cannibalism may have resulted from low food availability. The years 2013 and 2004 were quite rainy during the Bonelli's Eagle breeding season (January to May); mean rainfall values were higher (365 $\mathrm{mm}$ and $249 \mathrm{~mm}$, respectively) than average for this period for the whole study area (175 mm, AEMET 2013). Rainfall or severe weather can affect breeding performance in raptors (Kostrzewa and Kostrzewa 1990, Penteriani 1997), specially in raptor species that dwell in warm areas, such as Bonelli's Eagle (Moreno-Rueda et al. 2009, Muñoz 2013), probably by shortening the time an eagle has available for foraging (Hirons 1982), by reducing prey detectability, and by increasing the energy cost for gliding flight (Balbontín and Ferrer 2005). Thus, our observation seems to fit the trophic hypothesis (Mock and Forbes 1995), according to which an extra nestling in a brood represents a reservoir of nutrients, and its consumption by the parent Bonelli's Eagles allows the recovery of some of the considerable energetic costs of reproduction. The second possibility is that the cannibalistic parents exhibited an aberrant behavior (Korňan and Macek 2011).

We thank David Nesbitt for improving the English. JC had a postdoctoral contract jointly financed by the ESF and by the Junta de Comunidades de Castilla-La Mancha (JCCM, Spain), in the framework of the Operational Programme FSE 2007-2013. Finally, we thank Joan Real, Vincenzo Penteriani, and an anonymous referee for constructive comments on an earlier version of this report-Jesús Caro (e-mail address: jcaro@ugr.es), Departamento de Zoología, Facultad de Ciencias, University of Granada, E18071 Granada, Spain, and Instituto de Investigación en Recursos Cinegéticos-IREC (CSIC-UCLM-JCCM), Ronda de Toledo s/n. 13071, Ciudad Real, Spain; Diego Ontiveros and Juan M. Pleguezuelos, Departamento de Zoología, Facultad de Ciencias, University of Granada, E-18071 Granada, Spain.

\section{LITERATURE Cited}

AEMET. 2013. Datos climatológicos. http://www.aemet. es/es/serviciosclimaticos/datosclimatologicos (last accessed 15 December 2013).

Arroyo, B., J.M. Bueno, And V. PÉrez-Mellado. 1976. Biología de reproducción de una pareja de Hieraaetus fasciatus en España Central. Doñana, Acta Vertebrata 3:33-45.

Balbontín, J. and M. Ferrer. 2005. Condition of large brood in Bonelli's Eagle Hieraaetus fasciatus. Bird Study 52:37-41.

BirdLife InTERnATIONAL. 2004. Birds in Europe: population estimates, trends and conservation status. BirdLife Conservation Series number 12. BirdLife International, Cambridge, U.K.

Cramp, S. And K.E.L. Simmons. 1980. Handbook of the birds of Europe, the Middle East, and North Africa: the birds of the western Palearctic, Vol. 2. Hawks to bustards. Oxford University Press, Oxford, U.K.
DEL Moral, J.C. 2006. El águila perdicera en España. Población en 2005 y método de censo. SEO-BirdLife, Madrid, Spain.

Ebensperger, L. 1998. Strategies and counterstrategies to infanticide in mammals. Biological Reviews 73:321-346.

Elgar, M.A. AND B.J. CRESPI. 1992. Cannibalism: ecology and evolution among diverse taxa. Oxford University Press, New York, NY U.S.A.

Fox, L.R. 1975. Cannibalism in natural populations. Annual Review of Ecology and Systematics 6:87-106.

García-Dios, I.S. 2003. Siblicide and cannibalism in the Booted Eagle (Hieraaetus pennatus) in the Tietar Valley, central Spain. Journal of Raptor Research 37:261.

González, L., A. Margalida, R. SÁnchez, and J. Oria. 2006. Supplementary feeding as an effective tool for improving breeding success in the Spanish Imperial Eagle (Aquila adalberti). Biological Conservation 129:477-486.

Hernández-Matías, A., J. Real, M. Moleón, L. Palma, J.A. Sánchez-Zapata, R. Pradel, M. Carrete, J.M. GilSÁnchez, P. Beja, J. Balbontín, N. Vincent-Martin, A. Ravayrol, J.R. Benítez, B. Arroyo, C. Fernández, E. Ferreiro, AND J. García. 2013. From local monitoring to a broad-scale viability assessment: a case study for the Bonelli's Eagle in western Europe. Ecological Monographs 83:239-261.

Hirons, G.J.M. 1982. The effects of fluctuations in rodent numbers on breeding success of Tawny Owl Strix aluco. Mammal Review 14:155-157.

INGRAM, C. 1959. The importance of juvenile cannibalism in the breeding biology of certain birds of prey. Auk 76:218-226.

. 1962. Cannibalism by nestling Short-eared Owls. Auk 79:715.

KevLes, B. 1986. Females of the species: sex and survival in the animal kingdom. Harvard University Press, Cambridge, MA U.S.A.

KORŇAN, M. AND M. MACEK. 2011. Parental infanticide followed by cannibalism in Golden Eagles (Aquila chrysaetos). Journal of Raptor Research 45:95-96.

KostrzeWA, R. AND A. KostrzeWA. 1990. The relationship of spring and summer weather with density and breeding performance of the buzzard Buteo buteo, goshawk Accipiter gentilis and kestrel Falco tinnunculus. Ibis 132:550-559.

Mociño-Deloya, E., K. Setser, J.M. Pleguezuelos, A. KarDON, AND D. LAZCANO. 2009. Cannibalism of nonviable offspring by postparturient Mexican lance-headed rattlesnakes, Crotalus polystictus. Animal Behaviour 77:145-150.

Mock, D.W. AND L.S. Forbes. 1995. The evolution of parental optimism. Trends in Ecology and Evolution 10:130-134.

Moreno-Rueda, G., M. Pizarro, D. Ontiveros, and J.M. Pleguezuelos. 2009. The coexistence of the eagles $A q$ uila chrysaetos and Hieraaetus fasciatus increases with low human population density, intermediate temperature, and high prey diversity. Annales Zoologici Fennici 46:283-290. 
MuÑoz, A.R. 2013. Distribution models for Bonelli's Eagle (Aquila fasciata) at different spatio-temporal scales. Implications for management and conservation. Ph.D. dissertation, University of Malaga, Málaga, Spain.

Ontiveros, D. 1999. Selection of nest cliffs by Bonelli's Eagle (Hieraaetus fasciatus) in southeastern Spain. Journal of Raptor Research 33:110-116.

- J. Caro, and J.M. Plegulzullos. 2008. Possible functions of alternative nest in raptors: the case of Bonelli's Eagle. Journal of Ornithology 149:253-259.

Penteriani, V. 1997. Long-term study of a goshawk breeding population on a Mediterranean mountain (Abruzzi Apennines, central Italy): density, breeding performance and diet. Journal of Raptor Research 31:308-312.

PoLIS, G.A. 1981. The evolution and dynamics of intraspecific predation. Annual Review of Ecology and Systematics 12:225-251.

AND C.A. MYERs. 1985. A survey of intraspecific predation among reptiles and amphibians. Journal of Herpetology 19:99-107.

REAL, J. 1987. Evolución cronológica del régimen alimenticio de una población de Hieraaëtus fasciatus en Catalunya: factores causantes, adaptación y efectos. Suplemento Ricerca Biologica Selvaggina 12:185-205.
1991. L'àliga perdiguera Hieraaetus fasciatus a Catalunya: status, ecología tròfica, biologia reproductora i demografía. Ph.D. dissertation, University of Barcelona, Barcelona, Spain.

- AND S. MAÑOSA. 1990. Eagle owl (Bubo bubo) predation on juvenile Bonelli's Eagles (Hieraaetus fasciatus). Journal of Raptor Research 24:69-71.

— AND —. 1997. Demography and conservation of western European Bonelli's Eagle Hieraaetus fasciatus populations. Biological Conservation 79:59-66.

Solaro, C. AND H. SARASOla. 2012. First observation of infanticide and cannibalism in nest of Chimango Caracara (Milvago chimango). Journal of Raptor Research 46:412-413.

Stanback, M.T. AND W.D. KoEnig. 1992. Cannibalism in birds. Pages 277-298 in M.A. Elgar and B.J. Crespi [EDS.], Cannibalism: ecology and evolution among diverse taxa. Oxford University Press, New York, NY U.S.A.

Torres, A., P. Jordano, AND A. LeÓn. 1981. Aves de presa diurnas de la provincia de Córdoba. Publicaciones del Monte de Piedad y Caja de Ahorros de Córdoba, Córdoba, Spain.

Received 12 November 2013; accepted 29 January 2014 Associate Editor: Vincenzo Penteriani

\section{Proning BeHavior In CoOper's HaWks (ACCIPITER COOPERII)}

KEY WORDS: Cooper's Hawk; Accipiter cooperii; fledglings; group behavior; post-fledging; proning.

We here introduce a new term, proning, to name and describe an apparently undocumented behavior in postfledging Cooper's Hawks (Accipiter cooperii). We note the group aspect of this behavior in some cases and relate this phenomenon to the challenge of locating fledgling hawks during studies of the reproductive rate of this species and possibly of other raptors.

We observed fledglings well capable of flight in prone positions (i.e., proning), that is, lying with their whole bodies (tails included) along the axis of tree limbs or on the ground. The head of the proning bird is raised above the body, although we have observed proning fledglings with their heads lying on branches, apparently sleeping (eyelids closed; Fig. 1). When the proning bird was in a tree, its wings were sometimes offset from its sides, as if to grasp the branch (perhaps to secure contact) when the limb was only about as wide as the bird's body (Fig. 1). We have not detected vocalizations by proning birds.

Our observations stem from a 34-yr ongoing study of breeding Cooper's Hawks in Wisconsin in which we routinely make at least two visits to each nest, one or more to determine the presence of an incubating bird and another visit during which we climb to nests to count the number of young that have reached at least $18 \mathrm{~d}$ of age (or $70 \%$ of fledging age, ca. $25 \mathrm{~d}$ ), to record brood size, and to band young (Rosenfield et al. 2007b, 2013). We opportunistically visit some nest sites after young have fledged to trap adult birds and collect habitat data (e.g., Bielefeldt et al. 1998, Rosenfield et al. 1996, Trexel et al. 1999). During one 3-yr consecutive period, RNR routinely conducted another nest visit of about a maximum of $30 \mathrm{~min}$ to determine the number of fledged young (ca. 30-40 d old). During one of these visits, RNR first observed proning by a fledgling in a nest tree (nest extant).

LES made his observations of proning during daily and opportunistic observations of a brood of four fledglings (one male, three females) near an urban nest in Oshkosh, Wisconsin, 2013. LES's observations were facilitated by the relatively easy detection of young permitted by the sparse tree and shrub cover of this urban landscape.

During all hours of daylight, LES observed both male and female fledglings proning in the nest tree and in two 